\title{
Energy and Seismic Upgrading of R.C. Masonry Infilled Frame Buildings: A General Perspective
}

\author{
Anthimos S Anastasiadis* \\ Department of civil engineering, ASAnastasiadis \& Associates, Greece
}

Submission: June 19, 2017; Published: July 31, 2017

*Corresponding author: Anthimos S Anastasiadis, Department of civil engineering, ASAnastasiadis \& Associates, Consultant Engineers, Taskou Papageorgiou 10, 54631, Thessaloniki, Greece Email: anastasiadis@asacon.eu

\begin{abstract}
The present opinion paper attempts to briefly describe the problem and further on to provide with a conceptual view towards the mobilization of the civil engineering community to start investigate retrofitting procedures which integrates, in one solution system, both the energy and seismic upgrading of existing buildings by using insulation façade elements, which ensure the building physics along with the earthquake resistance performance.
\end{abstract}

Keywords: Energy; Seismic; Reinforced concrete frames; Infill masonry; Strengthening-upgrading, architectural surfaces; Facades; Resilient urban sites

\section{Introduction}

The build environment is strongly stressed by the earthquakes and climate change. The energy poverty and the seismic vulnerability of the existing building stock, for both the developed and underdeveloped countries, are recognized. Moreover, the seismic events and the climate conditions strongly affect the performance of building structures, hence representing the main cause of failure. Therefore, in order to protect the existing buildings a strategy which combines both the energy and seismic upgrading should be developed. The first one would lead to the reduction of the energy consumption, while the second one would provide earthquake resistant structures. Both of them must be ensured. It is clear that, in case of seismic action, an energy system connected with an unstable support will record a failure. Furthermore, an earthquake resistant structure, not properly energy protected, will consume much energy. Towards this direction new design procedures and especially new innovative construction techniques, and products, as well, should be developed.

Reinforced concrete infilled masonry frames represent a great percent of the existing building stock designed not conforming current level of technical knowledge. Such systems we can recognized in earthquake prone countries in Northern part of Europe, Balkan countries, Asia, U.S. and New Zealand, [1]. It is mostly used for residential, office, hospital, school and hotel buildings. Past earthquakes, for over 30 years, revealed the high vulnerability of the non-structural components and especially the infilled masonry-enclosure walls. It is clear that the nonstructural masonry could not support energy systems. Moreover, recent global action for reducing energy consumption in buildings leads to the application of such systems on seismically deficient supports. This is aggravated by the fact that generally non-structural components are not structurally designed. Thus, the collapse of the infilled masonry points out the failure of the energy system. As a consequence, the damage is duplicated and the losses are higher.

The present opinion paper attempts to briefly describe the problem and further on to provide with a conceptual view towards the mobilization of the civil engineering community to start investigate retrofitting procedures which integrates, both the energy and seismic upgrading of existing buildings by using façade energy systems, that ensure the thermal, cooling along with the earthquake resistance performance.

\section{A Conceptual View of Application}

In order to define the basic criteria for the energy and seismic upgrading, one can consider the following items:

a. The contribution of the masonry infills related to the stiffness and strength of the reinforced concrete frame is well recognized, [2,3]. As a function of structural detailing, geometrical dimensions, openings and positioning in the structure, we can observe positive and negative contribution of the masonry infill panel. However, with proper detailing 


\section{Civil Engineering Research Journal}

the negative impact can be reduced; further on, one can exploit the positive action, which when it is considered leads to the increasing of the stiffness and the strength of r.c. frame. Thus, a partial or integral improving of the earthquake behavior could be obtained.

b. Use of energy systems that will properly attached to the masonry infills will ensure an interaction with the supporting structure. So, the new element is composed by the existing masonry infill, the main energy component, the connectors and/or adhesives as well as other possible applied materials like fiber reinforced plastics or other textile mesh reinforcement materials. Thus, a new cladding component would be formed. With a suitable design and detailing they can provide stiffness and resistance both inplane and/or out-of plane. In this way, the integrated element would enhance energy and mechanical performance.

c. The new system (masonry infill and the energy component) must be fire resistant. In this direction special mortars should be used for finishes, while the use of steel or aluminum lightweight elements must be used with care.

d. Minimum disruption to the users. Attempt to materialize all the possible construction works only by using the external surface of the building and not the internal one, where the users develop their actions.

e. A pleasant architectural aspect, improving also the aesthetics of the existing structure.

The main idea is that the energy saving system to help protect the masonry infill, which further contributes to the stiffness and the resistance of the reinforced concrete frame. So, the new composite element provides an increased thickness, sectional area and moment of inertia. From earthquake performance point of view, an initial effort, in two levels, could be defined; the first one is to protect the integral system (i.e. ETICS + masonry infill), against failure, in low and frequent seismic actions; the second one is to protect the masonry infill (and if is possible along with the insulation board), in moderate to nearly severe earthquakes, while the decorative layer will fail. From constructional point of view, taking into account the aforementioned criteria the following conceptual solutions would be applied:

a. The classical external thermal insulation composite systems, ETICS, when it is properly attached to the masonry infill could help to the energy savings as well as to the inplane and out-of plane mechanical performance, [4]. b. The ventilated façade, which is a more advanced insulation solution. This system is comprised by a directly attached insulation board (EPS, XPS or Rockwool) on the masonry infill and a layer-gap in proper distance from the insulation board. The final decorative layer is connected on the steel frame, which also is attached to the masonry infill. Similar to the ETICS, this composite system when it is designed and detailed correctly would offer an enhanced performance due to its building physics and moment of inertia characteristics.

c. The above mentioned solutions, however, in this case by adding on the infill or on the insulation board, horizontally or vertically, different reinforced plastic bands or different steel meshes confining or stabilizing the whole composite system.

d. Prefabricated panels connected or bonded to the masonry infill, composed by insulation boards, concrete elements and different decorative finishes, finally formatting aesthetic architectural surfaces.

In the direction of exploiting any positive effect of the interaction between the energy and supporting systems, firstly, an experimental and numerical campaign should be carried out, analyzing the behavior in different levels of ground motion, also, studying and mitigating any negative effects, and secondly a design methodology and detailing solutions should be proposed.

\section{Concluding Remarks}

A holistic view is necessary to be taken involving structural, mechanical engineers and architects for aesthetic issues. The proper measures for retrofitting the existing building stock must combine at the same time the use of solutions that offer an integral protection against environmental actions. This is the only way to obtain a sustainable and resilient build environment.

\section{References}

1. World Housing Encyclopedia (2017) A joined project by EERI and IAEE.

2. Paulay T, Priestley MJN (1992) Seismic Design of Reinforced Concrete and Masonry Buildings. John Wiley and Sons, New York, USA.

3. Manos GC, Yasin B, Thaumpta J, Mpoufides D (1998) The Simulated Earthquake Response of two 7-story R.C. Planar Model Structures - A Shear Wall and a Frame with Masonry Infills. $6^{\text {th }}$ US National Earthquake Engineering Conference, Washington, USA.

4. Mosoarca M, Petrus C, Stoian V, Anastasiadis A (2016) Behaviour of masonry infills subjected to out-of-plane seismic actions. Part 2: Experimental testing. $16^{\text {th }}$ International Brick and Block Masonry Conference, Padova, CRC Press, Florida, USA, pp. 1293-1300. 
This work is licensed under Creative Commons Attribution 4.0 License

DOI: 10.19080/CERJ.2017.01.555558
Your next submission with Juniper Publishers will reach you the below assets

- Quality Editorial service

- Swift Peer Review

- Reprints availability

- E-prints Service

- Manuscript Podcast for convenient understanding

- Global attainment for your research

- Manuscript accessibility in different formats

( Pdf, E-pub, Full Text, Audio)

- Unceasing customer service

Track the below URL for one-step submission https://juniperpublishers.com/online-submission.php 